\title{
Duurzaam willen ontwikkelen
}

Citation for published version (APA):

Davidson, M. D. (2016). Duurzaam willen ontwikkelen. Maastricht University. https://doi.org/10.26481/spe.20160415md

Document status and date:

Published: 15/04/2016

DOI:

10.26481/spe.20160415md

Document Version:

Publisher's PDF, also known as Version of record

\section{Please check the document version of this publication:}

- A submitted manuscript is the version of the article upon submission and before peer-review. There can be important differences between the submitted version and the official published version of record.

People interested in the research are advised to contact the author for the final version of the publication, or visit the DOI to the publisher's website.

- The final author version and the galley proof are versions of the publication after peer review.

- The final published version features the final layout of the paper including the volume, issue and page numbers.

Link to publication

\footnotetext{
General rights rights.

- You may freely distribute the URL identifying the publication in the public portal. please follow below link for the End User Agreement:

www.umlib.nl/taverne-license

Take down policy

If you believe that this document breaches copyright please contact us at:

repository@maastrichtuniversity.nl

providing details and we will investigate your claim.
}

Copyright and moral rights for the publications made accessible in the public portal are retained by the authors and/or other copyright owners and it is a condition of accessing publications that users recognise and abide by the legal requirements associated with these

- Users may download and print one copy of any publication from the public portal for the purpose of private study or research.

- You may not further distribute the material or use it for any profit-making activity or commercial gain

If the publication is distributed under the terms of Article $25 \mathrm{fa}$ of the Dutch Copyright Act, indicated by the "Taverne" license above, 
Prof. dr. Marc D. Davidson

Faculty of

Humanities and Sciences

\section{Duurzaam willen ontwikkelen}


Duurzaam willen ontwikkelen 
ISBN: $978-90-5681-462-5$

NUR: 730

All rights reserved. No part of this publication may be reproduced, modified, stored in a retrieval system or made public without the prior written permission of the author or publisher. 


\title{
Duurzaam willen ontwikkelen
}

\author{
Rede \\ uitgesproken bij de aanvaarding van het ambt van \\ bijzonder hoogleraar 'Filosofie van duurzame ontwikkeling \\ vanuit humanistisch perspectief' aan de Faculty of \\ Humanities and Sciences van Maastricht University
}

Maastricht, 15 april 2016

Door Prof. dr. Marc D. Davidson 
Duurzaam willen ontwikkelen 
Mijnheer de Rector Magnificus, geachte aanwezigen,

Het is gebruikelijk om in een inaugurele rede te schetsen waar men vandaan komt en waar men naartoe wil. Dat is in mijn geval geen rechte weg. Ruim twintig jaar geleden, tijdens mijn promotieonderzoek in de natuurkunde, raakte ik gegrepen door de milieuproblematiek en wilde ik aan de oplossing daarvan mijn bijdrage leveren. Gezien mijn opleiding lag een carrière voor de hand in natuurwetenschappelijk onderzoek naar de invloed van de mens op het milieu. Of de ontwikkeling van schone technologieën zoals efficiëntere zonnecellen. Toch ben ik een andere weg ingeslagen. Ik geloofde toen niet - en geloof nu een kwart eeuw later alleen maar minder - dat de oplossing van duurzaamheidsvraagstukken gelegen is in meer natuurwetenschappelijke inzichten of meer technologische vindingen.

Neem bijvoorbeeld het mechanisme van het versterkte broeikaseffect, een van de centrale duurzaamheidsproblemen. Inzicht daarin hebben we al meer dan een eeuw. Sinds de industriële revolutie verbranden we massaal fossiele brandstoffen, zoals kolen, aardolie en aardgas, waardoor de concentratie van kooldioxide in de atmosfeer toeneemt. Deze dikkere deken van kooldioxide houdt de warmte van de aarde beter vast waardoor de gemiddelde temperatuur stijgt. De Zweedse wetenschapper Svante Arrhenius signaleerde dit mechanisme al in 1896 in zijn artikel "Over de invloed van koolzuur in de lucht op de temperatuur van de grond." Sinds 1990 rapporteert het Intergovernmental Panel on Climate Change, het IPCC, om de vijf jaar over de stand van de klimaatwetenschap. Het is elke keer weer nauwkeuriger en zekerder, maar het verschilt niet fundamenteel van wat we al meer dan een eeuw weten. Arrhenius sprak over vijf tot zes graden temperatuurstijging bij een verdubbeling van de concentratie van kooldioxide. Het IPCC (2014) geeft als beste schatting anderhalf tot vier en een halve graden, maar houdt ook zes graden voor mogelijk. Om deze getallen in perspectief te plaatsen: de afgelopen tien duizend jaar is de gemiddelde mondiale temperatuur niet meer dan één graad gestegen of gedaald ten opzichte van het gemiddelde van vijftien graden. Dat is dus vanaf het begin van de geschreven geschiedenis. Zijn die temperatuurstijgingen een probleem? Niet per se als ze zeer geleidelijk, over vele duizenden jaren plaatsvinden. Niet omdat de 
natuur zich dan via evolutie kan aanpassen - daarvoor is nog veel meer tijd nodig - maar omdat planten, dieren en gehele ecosystemen dan kunnen meeverhuizen met de verschuivende klimaatzones op aarde. Het is wél een probleem als het klimaat binnen enkele decennia verandert, zoals nu ten gevolge van menselijk handelen. Oftewel: we kennen het probleem. Of beter gezegd: we kunnen het weten. Want om te weten moeten we ook willen weten. Over dat willen later meer.

Wat de technologieën betreft om milieuproblemen op te lossen: er is noch een tekort aan beschikbare technologie, dat wil zeggen technieken die al op de plank liggen, noch aan het menselijk vernuft om nieuwe technologieën te ontwikkelen. Het menselijk vernuft is schier onbegrensd. Kijk naar de ontwikkeling van auto's, computers, mobiele telefoons en internet. Realiseert u zich de snelheid waarmee de mogelijkheden van deze technologieën zijn uitgebreid en hoe snel prijzen zijn gedaald. Waaraan in de maatschappij voldoende behoefte is, wordt razendsnel ontwikkeld en betaalbaar geproduceerd. Natuurlijk staan die behoeften niet los van wat er technologisch mogelijk is. Zij zijn mede een resultaat van het technologische aanbod zoals Harro van Lente, mijn voorganger op deze leerstoel, zou opmerken. Tegelijkertijd kan een nieuwe maatschappelijke vraag de technologische ontwikkeling wel degelijk sturen. Bekend is natuurlijk de bemande vlucht naar de maan in 1969, die acht jaar eerder door de Amerikaanse president Kennedy expliciet ten doel was gesteld. Maar ook veranderende normen kunnen de technologie sturen. Nadat kinderarbeid werd verboden, ontwikkelde zich snel de technologie die kinderarbeid overbodig maakte (Feenberg, 1999: 82). Of denk aan de razendsnelle ontwikkeling en productie van wapentuig tijdens de Wereldoorlogen. De geschiedenis van technologische ontwikkeling geeft daarom geen enkele reden tot twijfel: de technologieën die nodig zijn om minder fossiele brandstoffen te verbruiken, kunnen eveneens op korte termijn worden ontwikkeld en grootschalig ingezet op het moment dat de maatschappij daarom vraagt. En betaalbaar, zoals we ook zonder economische ontwrichting de samenleving hebben weten te verzadigen met breedbeeldtelevisies, koelkasten, computers en smartphones. Zelfs zónder verdere technologische vooruitgang zijn wij prima in staat goede, zinvolle levens te leiden met leefstijlen die 
substantieel minder fossiele brandstoffen vergen. Onze huidige consumptiepatronen en leefstijlen zijn niet de enige wegen tot geluk.

Maar als er noch een tekort is aan natuurwetenschappelijke kennis, noch aan de technologische mogelijkheden om de milieucrisis op te lossen, dan kan de bottleneck enkel liggen in de menselijke wil om de problemen aan te pakken. De vraag naar het hoe en waarom van die wil is echter noch een natuurwetenschappelijke, noch een technische vraag. Het is voornamelijk een filosofisch vraagstuk. Vandaar dat ik na mijn promotie in de natuurkunde een andere weg ben ingeslagen. Via een studie milieufilosofie en promotie bij respectievelijk de Socrates-hoogleraren Wouter Achterberg en Govert den Hartogh sta ik nu hier om het ambt te aanvaarden van bijzonder hoogleraar filosofie van duurzame ontwikkeling vanuit humanistisch perspectief. Filosofie van duurzame ontwikkeling vanuit humanistisch perspectief, hoe kijk ik daartegen aan?

\section{Diepere oorzaken van de milieucrisis}

Er is een groot aantal fundamentele oorzaken gesuggereerd voor de milieucrisis. Volgens Lynn White, auteur van het invloedrijke The Historical Roots of Our Ecological Crisis uit 1967, komt de milieucrisis vooral voort uit onze Joods-Christelijke wortels, uit het feit dat onze cultuur is doordrenkt met het Aristotelische en Bijbelse idee dat de natuur er enkel is om door de mens te worden gebruikt. De snelle ontwikkeling van wetenschap en techniek heeft ons superioriteitsgevoel over de natuur alleen maar versterkt. Dergelijke cultureel bepaalde waardepatronen kunnen de oplossing van de crisis zeker belemmeren. Toch lijken zij eerder een rationalisatie te zijn van onze natuurlijke drijfveren dan een eerste oorzaak (zie ook Kunneman, 2007: 75). Als we op wat grotere schaal kijken, is er immers weinig onnatuurlijks aan de wijze waarop de mens momenteel op de grenzen van het aardse ecosysteem afstevent. In de natuur leven de meeste soorten weliswaar in dynamisch evenwicht met hun omgeving, maar dan wel op het niveau van een strijd om het bestaan, zoals Darwin dat noemde. Slechts wanneer een soort een nieuw voordeel ten opzichte van andere soorten ontwikkelt, kan zij tijdelijk in overvloed leven en in populatie toenemen. Dat duurt echter totdat het door een te grote populatie en daarmee samenhangende uitputting van voorraden weer wordt 
teruggeworpen op het niveau van strijd om het bestaan. Voorlopig verschilt de mens in die natuurlijke cyclus niet van andere soorten. Evenmin in de schaal van haar invloed: miljarden jaren geleden, tijdens het Proterozoïcum, verhoogden blauwalgen de zuurstofconcentratie in de atmosfeer dusdanig dat massale en mondiale extinctie plaatsvond van anaerobe bacteriën en algen voor wie zuurstof giftig is. In het huidige tijdperk heeft de mens dankzij zijn intelligentie voordeel ten opzichte van andere soorten en leeft daardoor met name de laatste eeuwen in relatieve voorspoed en vermenigvuldigt zich overeenkomstig. Leefden we in 1800 nog met één miljard mensen op deze planeet, inmiddels zijn we met zeven miljard. De grenzen aan deze groei komen echter duidelijk in zicht, en daarmee wellicht ook aan het Antropoceen, zoals het geologische tijdperk wordt aangeduid waarin de mens een blijvend spoor achterlaat in de geologie van de aarde (Crutzen, 2006).

Juist een duurzame ontwikkeling, een ontwikkeling waarbij de mens haar kwaliteit van leven voor onbeperkte tijd ruim boven het niveau van een strijd om het bestaan houdt, zal dan ook een kunststuk vormen dat nog niet eerder in de natuur is vertoond. Een duurzame ontwikkeling is daarom zo onnatuurlijk als het maar kan. Een duurzame ontwikkeling vergt immers een zelfopgelegde matiging in zowel consumptie als voortplanting die ingaat tegen onze natuurlijke drijfveren. Voor dit kunststuk zal de mens dan ook een beroep moeten doen op bij uitstek menselijke vermogens. Allereerst het vermogen de gevolgen van onze huidige handelingen te overzien, hoewel deze gevolgen zich ver in ruimte en tijd uitstrekken, ver voorbij ons directe blikveld. Ten tweede het vermogen in vrijheid keuzes te maken: hoewel wij ons momenteel niet wezenlijk anders dan andere organismen gedragen, zijn wij vrij een duurzame ontwikkeling te kiezen; de ecologische crisis is geen noodzakelijkheid. Daarvoor dienen wij wel onszelf te begrijpen en onze innerlijke drijfveren te herkennen. Ten derde het vermogen te handelen vanuit innerlijke waarden. Zo zijn wij in staat ons te bekommeren om onze medemens, hier en nu maar ook elders en later, en om de niet-menselijke natuur. Dat wij deze vermogens hebben, is juist kerngedachte van het humanisme. 


\section{Tragedy of the Commons}

Een tweede gangbare verklaring voor de milieuproblematiek is dat zij een collectief handelingsprobleem vormt. Wat dat is, is het meest bekend geworden door het artikel The Tragedy of the Commons dat bioloog Garrett Hardin in 1968 in Science publiceerde. Hardin geeft het voorbeeld van een gemeenschappelijke weide waar individuele herders voor de keuze staan om hun kudde uit te breiden of niet. Hardin laat zien dat zolang de weide ongecontroleerd gemeenschappelijk bezit blijft, een catastrofe in het verschiet ligt. Iedere herder maakt immers de afweging dat de voordelen van het uitbreiden van de eigen kudde zélf worden geplukt in de vorm van extra wol en vlees, maar dat de nadelen in de vorm van een afname van de hoeveelheid gras worden afgewenteld op alle herders. Het gevolg is dat alle herders hun kudde uitbreiden en uiteindelijk door overbegrazing alle dieren van de honger omkomen. De oplossing ligt volgens Hardin in 'wederzijdse dwang, wederzijds afgesproken'. Bijvoorbeeld door elke herder een eigen deel van de weide toe te wijzen. Dan heeft elke herder individueel reden om de omvang van de eigen kudde te beperken. De Tragedy of the Commons staat symbool voor de meeste milieuproblemen, in ieder geval voor alle internationale milieuproblemen, zoals klimaatverandering, overbevissing van de zeeën en oceanen, en verlies aan biodiversiteit.

Collectieve handelingsproblemen zijn lastig, zeker op mondiale schaal. De oplossing vraagt immers afspraken tussen alle of tenminste het merendeel van de landen. Lastig, maar niet onmogelijk. In 1974 publiceerden de Amerikaanse onderzoekers Frank Rowland en Mario Molina een rapport over het mogelijke verband tussen de uitstoot van CFK's en afbraak van de ozonlaag. De ozonlaag in de stratosfeer beschermt het leven op aarde tegen UVstraling van de zon. CFK's zijn stoffen die voorheen grootschalig werden gebruikt als koelvloeistoffen in koelkasten en als drijfgassen in spuitbussen. In 1987, dertien jaar na het rapport van Rowland en Molina, werd in Montreal een mondiaal akkoord gesloten om het gebruik van CFK's terug te dringen. Het akkoord is succesvol en inmiddels herstelt de ozonlaag zich weer. Wederom: als de wereld het wil, zijn de problemen op te lossen. Waarom dan niet bij problemen zoals klimaatverandering? Laat er geen misverstand over bestaan: ondanks alle politieke euforie over het klimaatakkoord dat 
eind vorig jaar in Parijs werd gesloten, is de wetenschappelijke wereld het erover eens dat dat akkoord absoluut onvoldoende en te vrijblijvend is.

\section{Kosten}

Nu kan worden opgemerkt dat voor het uitfaseren van CFK's een technological fix voorhanden was: er bleken relatief goedkope alternatieven beschikbaar. Het probleem bleek oplosbaar zonder dat burgers en consumenten daarvan significant iets merkten in hun portemonnee of leefstijl. Zo een technological fix is niet voorhanden voor de aanpak van klimaatverandering. Het gebruik van fossiele brandstoffen zit zo fundamenteel verweven in onze economie dat het verminderen van het gebruik onmogelijk is zonder substantiële kosten en aanpassing van onze leefstijlen. We kunnen veel zuiniger met energie omgaan, zoals door het vervangen van gloeilampen door ledlampen, en we kunnen alle energie die we nodig hebben opwekken met vernieuwbare bronnen zoals wind- en zonne-energie. Maar aan beide opties hangen behoorlijke prijskaartjes. Het kan ook betekenen dat we onze leefstijlen moeten aanpassen: de verwarming iets lager zetten en geen vakanties aan de andere kant van de wereldbol. Desondanks zijn het alleszins draagbare kosten. Het IPCC schat de kosten om de temperatuurstijging tot twee graden te beperken op circa $3 \%$ van het mondiale bruto binnenlands product, ruim tweeduizend miljard Dollar per jaar. Dat is veel geld. Toch is het blijkbaar op te brengen wanneer we iets een probleem vinden. Volgens Joseph Stieglitz, Nobelprijswinnaar in de economie, en Linda Bilmes heeft de oorlog in Irak de Verenigde Staten circa drieduizend miljard dollar gekost (Stiglitz and Bilmes, 2008; zie ook Orszag, 2007). Als we dat over een jaar of tien uitstrijken, komt dat neer op circa 300 miljard dollar per jaar oftewel eveneens enkele procenten van het Amerikaanse BBP. Ook in leefstijl zijn de kosten hoog: voor de war on terror zijn Amerikanen bereid geweest de overheid vergaande bevoegdheden te geven ten koste van gekoesterde persoonlijke privacy. Kortom, ook de kosten van klimaatbeleid lijken niet de werkelijke bottleneck. 


\section{Onzekerheid}

Wellicht ligt het probleem in de onzekerheid waarmee klimaatverandering is omgeven. Hoewel klimaatverandering complex is, lijkt ook daar geen wezenlijk probleem te liggen. Zoals al eerder gememoreerd, kennen we al meer dan een eeuw het mechanisme van klimaatverandering. Wat we nog niet weten zijn de details. In ons dagelijks leven komt het zelden voor dat we absolute zekerheid verlangen. We betalen verzekeringspremies om ons voor allerlei onheil te behoeden zonder te weten hoeveel risico we werkelijk lopen. We sluiten inboedelverzekeringen af zonder zelf enig idee te hebben van de kans op brand. We zouden een vliegtuig mijden bij de minste geruchten over mankementen. Stelt u zich namelijk de volgende situatie voor: u bent van plan het vliegtuig te nemen, maar honderd ingenieurs stellen dat er mankementen zijn en raden $\mathrm{u}$ aan de trein te nemen. De trein is echter trager en duurder. Twee andere ingenieurs stellen het vliegtuig ook te hebben gecontroleerd en geen mankementen te zien. Als leek heeft $u$ geen mogelijkheid het werk van de ingenieurs zelf te beoordelen. Ik neem aan dat $u$ de trein neemt. In het geval van klimaatverandering volgt een groot deel van de maatschappij de aanbevelingen van de twee ingenieurs. Dat is opvallend.

\section{Toekomstige generaties}

Waarin verschillen de duurzaamheidsvraagstukken zoals klimaatverandering, de inzet van kernenergie en het verlies van mondiale biodiversiteit van de problemen die de mensheid wel bereid blijkt aan te pakken? Eén wezenlijk verschil is dat de werkelijke duurzaamheidsproblemen niet in de eerste plaats onszelf treffen, maar vooral toekomstige generaties. Neem de klimaatproblematiek. Door de inertie van de oceanen duurt het tientallen jaren voordat het verbranden van fossiele brandstoffen leidt tot een toename van de gemiddelde temperatuur. Daarnaast duurt het honderden tot duizenden jaren voordat eenmaal uitgestoten kooldioxide weer uit de atmosfeer wordt opgenomen. Als wij vandaag al tekenen van klimaatverandering waarnemen, dan is dat niet het gevolg van ons eigen handelen, maar dat van onze voorouders. Wanneer wij vandaag het roer omgooien, zullen wijzelf daarvan tijdens ons leven niet heel veel vruchten plukken, maar vooral toekomstige generaties. 
Wij hebben kortom geen direct eigenbelang bij de aanpak van de klimaatproblematiek. Anders gezegd: wij hebben wel belang bij het ons aanpassen aan klimaatverandering, bijvoorbeeld door hogere dijken te bouwen, maar niet bij het voorkomen daarvan. Wanneer het om ons eigenbelang gaat, het belang van de huidige generaties, dan is er geen wezenlijk duurzaamheidprobleem. En daarmee zijn we gekomen op de meest fundamentele bottleneck voor een duurzame ontwikkeling: wij hechten onvoldoende waarde aan het welzijn van toekomstige generaties.

\section{Plichten jegens toekomstige generaties}

Waarom zouden we ons überhaupt om hun welzijn bekommeren? 'Wat hebben zij ooit voor mij gedaan?' vroeg de komiek Groucho Marx zich eens af. De meest voor de hand liggende reden is dat wij anderen niet behoren te schaden. Het is één van de meest fundamentele morele gedachten. Toch ligt het in het geval van toekomstige generaties verrassend ingewikkeld. Mensen die in de verre toekomst leven, kúnnen wij namelijk niet schaden. De reden is dat wie die mensen zullen zijn afhangt van de beslissingen die we nu nemen. Laten we klimaatverandering op zijn beloop, dan leeft over honderd jaar bijvoorbeeld Kees. Maar voeren we streng klimaatbeleid, dan neemt de geschiedenis een andere wending: andere mensen zullen elkaar ontmoeten en andere kinderen verwekken. Dan zal Kees niet geboren worden, maar bijvoorbeeld Marie. Zoals filosoof Derek Parfit (1984: 361) het uitdrukte: hoe velen van ons kunnen werkelijk claimen dat zelfs als spoorwegen en auto's niet waren uitgevonden ikzelf toch zou zijn geboren? Het is daarom fundamenteel onmogelijk om Kees een stabiel klimaat te garanderen. Zonder klimaatverandering bestaat er geen Kees. Maar dan brengen we Kees dus ook geen schade toe. Dit botst sterk met onze morele intuïties. Parfit noemde dit het non-identiteitsprobleem. Het achtervolgt milieufilosofen al veertig jaar en naar mijn inzicht is er nog geen afdoende oplossing gevonden.

In praktijk is dat zelfs nog niet het wezenlijke probleem. Stel dat we toekomstige generaties wél onrecht zouden kunnen aandoen, zouden we dan gemotiveerd zijn om dat onrecht te voorkomen? Helaas liggen er wat psychologische beren op de weg. Mensen blijken nauwelijks gehoor te geven aan morele plichten jegens de 
ander zonder die ander te zien. Vandaar dat inzamelingsacties door hulporganisaties in het algemeen zinloos zijn eer beeldmateriaal voorhanden is. Beeldmateriaal van toekomstige generaties is echter per definitie onmogelijk. Dat ondergraaft de motivatie van de huidige generaties om plichten jegens het nageslacht serieus te nemen. ${ }^{1}$ Kortom, van alleen onze plichten jegens het nageslacht moeten we niet teveel verwachten.

\section{Zelftranscendentie}

Uit welke motivatiebronnen kunnen we dan wél putten om te komen tot een duurzame ontwikkeling? Naar mijn mening zal deze uiteindelijk moeten worden gevonden in onze behoefte aan zelftranscendentie en zingeving. Bij de term zelftranscendentie moet $\mathrm{u}$ niet denken aan iets mystieks zoals een ontkoppeling van geest en lichaam, maar simpelweg aan de behoefte deel uit te maken van en bij te dragen aan iets dat buiten jezelf ligt. Je identiteit verbonden zien met Maastricht University en willen bijdragen aan haar voortbestaan en succes, is een voorbeeld van zelftranscendentie. Maar ook het schrijven van boeken, het voortzetten van tradities, familieleven en het opzetten van een eigen bedrijf kunnen uitingen zijn van zelftranscendentie.

Waarom zie ik dit als een hoopvol motief voor een duurzame ontwikkeling? Ten eerste omdat psychologisch onderzoek toont dat de behoefte aan zelftranscendentie algemeen menselijk is en de vervulling van die behoefte zelfs noodzakelijk voor geestelijke gezondheid. Wij mensen hebben behoefte onszelf en onze handelingen te kunnen plaatsen in een raamwerk dat groter is dan onszelf, dat buiten onszelf ligt. Volgens ontwikkelingspsychologen komt deze behoefte voort uit onze behoefte aan stabiliteit en bestendigheid. We weten dat we zelf sterfelijk zijn, maar onze geest heeft een groter raamwerk nodig dat stabiel blijft. Bovendien willen

\footnotetext{
${ }^{1}$ In principe kan fictie in de vorm van literatuur en film empathie ten opzichte van het lot van toekomstige generaties bevorderen en ons met hen laten identificeren, net zoals het boek Uncle Tom's Cabin dat deed voor de slaven in de Verenigde Staten twee eeuwen eerder. Denk aan films zoals Waterworld, The Day After Tomorrow en Interstellar. Toch blijft de werking beperkt zonder dat parallel daaraan ook feitelijk beeldmateriaal voor handen is.
} 
wij aan dat raamwerk waarde kunnen hechten, waardoor wij in staat zijn waarde aan ons eigen leven te verbinden. Tenslotte hebben wij de behoefte om aan dat grotere raamwerk bij te dragen, een verschil te maken, hoe beperkt ook. Hebben we wel een zingevingskader, maar zijn we niet in staat enige link te leggen tussen dat kader en ons eigen leven, denk aan de fabrieksarbeider type Charlie Chaplin in Modern Times, dan kan dat leiden tot vervreemding, zoals Karl Marx dat zou noemen, en depressiviteit.

Hoewel de behoefte aan zelftranscendentie algemeen menselijk is, zullen weinigen continu en actief over deze zaken nadenken; meestal nemen we ons zingevingskader for granted. En als we daarover wél nadenken, hoeven we daarvan niet vrolijker te worden. Voor velen is een midlifecrisis niets anders dan het moment waarop men na een half leven met de paplepel andermans zingevingskaders te hebben binnengekregen die voor het eerst ter discussie stelt. Is het nou allemaal zinvol wat ik doe, heeft mijn leven wel betekenis? Hoe dan ook: men zal óf het oude zingevingskader moeten omarmen óf een nieuw kader moeten vinden om weer in balans te komen. Psycholoog Abraham Maslow drukt het zo uit (1968: 206):

\begin{abstract}
"We leren dat de toestand waarin men geen systeem van waarden heeft psychopathogeen is. De mens heeft een raamwerk van waarden nodig, een levensfilosofie, een religie of surrogaat daarvoor, om naar te leven en te begrijpen, ongeveer op dezelfde manier waarop hij zonlicht, calcium of liefde nodig heeft."
\end{abstract}

De tweede reden dat de behoefte aan zelftranscendentie en zingeving hoopvolle motieven zijn voor een duurzame ontwikkeling, is dat zelftranscendentie en zingeving over het algemeen continuïteit en behoud veronderstellen van dat wat wij van waarde vinden. Hoewel er activiteiten zijn die juist waarde ontlenen aan hun eindigheid en uniciteit, zoals een vakantie op Bora Bora, veronderstellen de meeste van de activiteiten die wij als zinvol en zingevend ervaren een open toekomst. ${ }^{2}$ Het is tegenstrijdig om als

\footnotetext{
${ }^{2}$ Wouter Achterberg geeft identificatie met de natuur als voorbeeld van een zingevingskader (Achterberg, 1992: 12). Wil deze identificatie zingevend zijn, dan veronderstelt deze eveneens continuïteit van de natuur.
} 
fanatiek supporter te juichen voor Ajax of MVV, maar dat het je niet uitmaakt als met je eigen dood je club meegaat in je graf. Of je ziel en zaligheid te leggen in het bedrijf dat je hebt opgericht, maar dat het je niet uitmaakt als het bedrijf failliet zou gaan na je pensionering. Of in mijn geval: wetenschappelijke artikelen te publiceren en voor mijn familie te zorgen, maar dat het mij niet interesseert als na mijn dood ook het hele wetenschappelijke vakgebied en mijn familie zouden ophouden te bestaan. Oftewel, dat wat werkelijk betekenis aan ons leven geeft, is een bijdrage te leveren aan datgene dat ons overleeft. Op politieke schaal vinden we dit idee terug in de omschrijving die Edmund Burke geeft van de samenleving in zijn Reflections on the revolution in France uit 1790:

"De samenleving is een partnerschap. Het is een partnerschap in alle wetenschappen; een partnerschap in alle kunsten; een partnerschap in alle deugden en in alle perfectie. Omdat de doeleinden van zo'n partnerschap niet kunnen worden behaald binnen enkele generaties, wordt het niet alleen een partnerschap tussen de levenden, maar tussen de levenden, de doden, en diegenen die nog geboren moeten worden."

Wanneer wij de samenleving inderdaad als zo een partnerschap zien, wanneer wij inzien hoe onze mogelijkheden nu een betekenisvol leven te leiden afhangen van een open toekomst, waarin toekomstige generaties de projecten die wij nu als waardevol zien kunnen voortzetten. Wanneer wij dat inzien, dan staat het belang van een duurzame ontwikkeling buiten kijf. Een onduurzame ontwikkeling verkort de houdbaarheidsdatum van vrijwel alles wat wij van waarde vinden. Zo bedreigt klimaatverandering de voortzetting van vele activiteiten die betekenis geven aan ons leven. Kort samengevat: ieder mens heeft behoefte zich ingebed te zien in en bij te dragen aan iets dat groter is dan zichzelf, iets dat het eigen leven overleeft. Een duurzame ontwikkeling is een voorwaarde dat deze behoefte kan worden vervuld, dat de toekomst open blijft.

\section{Individualisme}

Maar ik noemde zelftranscendentie een hoopvolle motivatie. Want in werkelijkheid blijkt uit weinig dat de maatschappij momenteel 
vanwege dit motief de weg naar een duurzame ontwikkeling inslaat. Daarvoor zijn tenminste twee redenen te geven. De eerste is dat de meeste mensen van nature een beperkte tijdshorizon hebben, terwijl zoals gezegd duurzaamheidsproblemen vooral de verre toekomst betreffen. Volgens milieufilosoof Dale Jamieson (2014: 102) ontsnappen duurzaamheidproblemen zoals klimaatverandering aan de vorm van aandacht waarmee de evolutie ons heeft opgezadeld: een versterkte aandacht voor plotselinge bewegingen van middelgrote objecten die visueel kunnen worden waargenomen. Toch hebben mensen sociale en politieke structuren weten te ontwikkelen die het mogelijk maken de beperkingen van de individuele blik te overstijgen. David Hume zag in de menselijke kortzichtigheid zelfs de belangrijkste bestaansgrond van overheid en maatschappij. ${ }^{3}$ Een goed georganiseerde samenleving weet en ziet immers meer dan het individu. Denk aan de verplichte bijdrage aan pensioenvoorzieningen, waarbij de overheid heel concreet mensen beschermt tegen een te korte termijnblik. Of denk aan het IPCC dat is opgericht omdat de gemiddelde burger onmogelijk de state of the art van de klimaatwetenschappen kan overzien. Maar om de overheid verder te laten kijken dan onze individuele blik, moeten burgers dat wel van hun overheid vragen en haar daarin vertrouwen. En daar wringt het in ons tijdsgewricht nogal.

Dat brengt me op de tweede reden. De vorige reden die ik noemde betrof onvermogen om in de verre toekomst te kijken. De tweede reden betreft desinteresse in de verre toekomst: een moderne blikvernauwing waardoor wij onszelf niet meer zien als schakel en partner in een lange intergenerationele keten, maar waardoor wij waarde enkel in ons zelf zoeken, slechts in het eigen leven tussen geboorte en dood. Sinds de Verlichting is met de toenemende individualisering het belang van religie en traditie afgenomen. Aan de Verlichting danken wij een rationelere blik op de werkelijkheid en het mogen bekritiseren van het geloof in hogere machten. Ook

\footnotetext{
3 "Here then is the origin of civil government and society. Men are not able radically to cure, either in themselves or others, that narrowness of soul, which makes them prefer the present to the remote. They cannot change their natures. All they can do is to change their situation, and render the observance of justice the immediate interest of some particular persons, and its violation their more remote." (Hume, 1739: book III, chapter II, §7).
} 
danken wij aan de Verlichting een waardering van het individu: de idee van de mens als een van nature rationeel, autonoom en onafhankelijk wezen met bijbehorende individuele rechten en plichten. Helaas lijkt met deze toegenomen individuele vrijheid ook het kind met het badwater te zijn weggespoeld. We hebben niet alleen de individuele vrijheid gekregen om zelf te kiezen waaraan wij waarde hechten en hoe wij aan ons leven betekenis geven, maar ook ervoor gekozen om die waarde vooral in onszelf te zoeken. Volgens de Amerikaanse psycholoog Roy Baumeister (1991: 78) is er in de moderne tijd, ter vervanging van de verloren gegane zingevingskaders, een fascinatie met het zelf ontstaan, een focus op persoonlijke identiteit als bron van alle waarde. We zien deze fascinatie met het zelf, het tegenovergestelde van zelftranscendentie, tegenwoordig letterlijk tot uitdrukking komen in de talloze selfies op Facebook.

Begrijp dit niet verkeerd: de moderne fascinatie met het zelf impliceert nog geen egoïsme. Het is verenigbaar met medemenselijkheid en respect voor andermans autonomie, oftewel met de erkenning dat ook anderen een gelijkwaardig zelf hebben. ${ }^{4}$ Maar het is een stuk minder verenigbaar met zelftranscendente waarden, waarden die niet zozeer in het eigen of andermans zelf liggen maar in gedeelde praktijken. Ook de beroemde Brundtlanddefinitie van duurzaamheid kan men zien als een symptoom van dit moderne individualisme. Volgens de commissie Brundtland is een duurzame ontwikkeling "een ontwikkeling die voorziet in de behoeften van de huidige generaties zonder het vermogen in gevaar te brengen van toekomstige generaties om in hun eigen behoeften te voorzien" (WCED, 1987: 8). In deze formulering zijn de generaties verworden tot los zand. De toekomstige generaties waarover de commissie Brundtland spreekt, hadden evengoed op een andere planeet of op een ander continent kunnen leven: anderen die geen partners zijn in generatie-overschrijdende projecten, tradities en praktijken, maar anderen tegenover wie wij plichten ervaren omdat wij toevallig van hun bestaan weten en ons realiseren dat wij hen in potentie kunnen schaden. Duurzaamheid

\footnotetext{
${ }^{4}$ Volgens Kunneman (2005) gaat het zelfs verder: het dikke ik dat vooral geïnteresseerd is in de eigen autonomie, maar niet in die van de ander.
} 
slechts uit medemenselijkheid en erkenning van de autonomie van toekomstige generaties (zie ook O’Neill, 1993: 27).

\section{Marktmaatschappij}

Dit individualisme, deze beperking van waarde tot het individuele zelf, wordt versterkt door zowel ons economische als ons politieke systeem. De gangbare gedachte onder economen is dat onze behoeften, voorkeuren en waarden aan de vrije markt voorafgaan en daarom onder invloed van de vrije markt niet veranderen. ${ }^{5}$ De vrije markt zou enkel een efficiënt allocatiemechanisme zijn, een middel om productieve activiteiten te organiseren en de maatschappelijke welvaart te verhogen. De vrije markt wordt bejubeld omdat marktprikkels het best zouden aansluiten bij de drijfveren van de mens. Tenminste, wanneer men de mens reduceert tot homo economicus: de mens die rationeel vanuit eigenbelang handelt. De homo economicus blijkt echter een selffulfilling prophesy. Vele onderzoeken bevestigen dat marktprikkels mensen juist opvoeden vanuit eigenbelang te handelen (Titmuss, 1971; Frank et al., 1993; Bowles, 2008; Schwartz, 2012; Falk \& Szech, 2013). De vrije markt voedt mensen op anderen als concurrenten te zien in plaats van partners in gedeelde projecten (Keat and Abercrombie, 1991: 216-30; Walsh, 2001) en holt daarmee deelname uit aan praktijken waarvan de producten alle deelnemers ten goede komen. ${ }^{67}$ En dat zijn juist die praktijken die mensen als meest zingevend ervaren.

\footnotetext{
${ }^{5}$ Dat was echter zeker geen gangbare gedachte onder de grondleggers van het economisch denken. Volgens optimisten, zoals Montesqieu, bevorderde de vrije markt zelfs deugden zoals eerlijkheid en ijver. Zie bijvoorbeeld Montesqieu's idee van 'doux commerce' (1748). Anderen waren echter minder optimistisch. Adam Smith wees erop dat naarmate werk in de vrije markt meer gespecialiseerd raakt, werknemers de mentale capaciteiten kunnen verliezen om deel te nemen aan maatschappelijke besluitvorming (1776: Book 5, Chapter 1, Part 3, Article 2).

${ }^{6}$ MacIntyre (1985) noemt dat 'internal goods'.

${ }^{7}$ Wolff (2004) betwijfelt dit en geeft als voorbeeld sport en de Olympische beweging. Commercialisering van de sport heeft geenszins de traditie van sport geërodeerd.
} 
Met name de laatste decennia is de reikwijdte van de vrije markt sterk toegenomen. Vooral onder invloed van de politieke neoliberale ideologie dat enkel een onbegrensde vrije markt verenigbaar zou zijn met individuele vrijheid en welvaart. ${ }^{8}$ Zoals filosoof Michael Sandel het noemt, zijn we ongemerkt overgegaan van het hebben van een markteconomie naar het zijn van een marktmaatschappij: een maatschappij waarin marktrelaties, marktprikkels en marktwaarden alle aspecten van het leven domineren. Een maatschappij waarin elk aspect van het leven handelswaar is geworden: van donororganen tot het ontlopen van de dienstplicht en het mogen adverteren in het klaslokaal (Sandel, 2000, 2012; Satz, 2010: 45). Het mag niet verbazen dat wanneer marktrelaties, marktprikkels en marktwaarden doordringen in activiteiten die men juist als meest zingevend ervaart, zoals familieleven, zorg en wetenschap, hun zingevende waarde erodeert. De erosie van Burke's samenleving als partnerschap tussen de generaties culmineert in Margaret Thatcher's "There is no such thing as society" (1987).

Kortom, de moderne fascinatie met het zelf, versterkt door marktmaatschappij en neoliberalisme, lijkt zowel het inzicht uit te hollen dat wij deel uitmaken van een generatie-overstijgend project als de behoefte daaraan. En deze behoefte is op zijn beurt essentieel voor de motivatie om duurzaam te willen ontwikkelen. Daarmee ben ik aangeland bij de meest wezenlijke bottleneck voor een duurzame ontwikkeling. Geen tekort aan natuurwetenschappelijke inzichten of technische vindingen, maar onwil om de problematiek aan te pakken door een doorgeschoten individualisme.

\section{Toekomstig onderzoek}

Tot zover de probleemanalyse. De oplossingen moet ik u echter schuldig blijven. Onderzoek daarnaar vormt juist de kern van mijn leeropdracht. Ik zal mij dan ook de komende jaren richten op de volgende vragen. Ten eerste: hoe vinden we een juiste balans tussen individuele vrijheid en een inrichting van de samenleving die partnerschap tussen de generaties en vertrouwen in de overheid voedt? Is het nodig grenzen aan de markt te stellen en zo ja, welke

\footnotetext{
${ }^{8}$ Grondleggers van de neoliberale ideologie zijn met name Friedrich Hayek, Milton Friedman en Ayn Rand.
} 
morele rechtvaardiging hebben we daarvoor? In hoeverre is het liberalisme van John Rawls en Ronald Dworkin, in staat om de lange termijn te beschermen? Hoewel dit liberalisme in tegenstelling tot het neoliberalisme geen bezwaar ziet tegen een krachtige overheid die bijvoorbeeld welvaart herverdeelt, dient deze overheid wel strikt neutraal te zijn ten aanzien van verschillende opvattingen over het goede leven. Stimuleert of erodeert deze neutraliteit partnerschap tussen de generaties? Er zit duidelijk een spanning tussen de liberale waarden van autonomie en de perfectionistische idealen die dat partnerschap ten doel kunnen hebben (Raz, 1986: 162; Kymlicka, 1989: 894-5).

Dezelfde spanning wordt weerspiegeld in het humanisme. Vandaar dat vanuit een tweede set vragen het humanisme kritisch zal worden bezien. Een centrale gedachte in het humanisme is dat er geen leven is na de dood en we daarom maar één leven hebben te leiden. 'Dit leven is ons volledige bestaan' schrijft Andrew Copson voorzitter van het Britse Humanistisch Verbond in de inleiding van The Wiley Blackwell Handbook of Humanism (Copson and Grayling 2015). 'We zullen als personen nooit verder ontwikkelen dan in dit leven: er is geen toekomst waarin voltooiing kan plaatsvinden'. Vandaar de humanistische opdracht tot zelfontplooiing en geluk tijdens dat ene leven. Maar letterlijk genomen is het idee dat er geen leven na de dood is al onjuist. Als ik hier nu dood neerval, zit u daar nog levend en wel. En ook als wij allen er niet meer zijn, zullen er toekomstige generaties zijn. Er is dus wel degelijk leven na de dood. Ook in sterkere zin. In deze oratie heb ik gepoogd duidelijk te maken dat wat betekenis geeft aan ons leven, dat wat wij als meest zinvol ervaren, juist die activiteiten zijn waarvan de ontplooiing en voltooiing ons individuele leven overstijgen. In die zin ademt de humanistische kernwaarde van zelfontplooiing dezelfde moderne fascinatie met het zelf en persoonlijke identiteit die eerder door Roy Baumeister werd gesignaleerd. Hiermee is niet gezegd dat er geen humanistische filosofen hebben gewezen op het belang van zelftranscendente waarden en zingeving. Het humanisme is een genuanceerd en flexibel gedachtegoed. In navolging van Hendrik Pos, een van de medeoprichters van het Nederlands Humanistisch Verbond, schrijft Peter Derkx (2011: 99) dat 'wie zichzelf wil ontplooien zich in elk geval ook moet richten op een zaak buiten het zelf'. In die formulering blijft echter een spanning zitten. Kan een 
waarde die buiten het zelf ligt een middel zijn tot ontplooiing van het zelf? Draait men de hiërarchie van waarden dan niet om?

Eerdere Socrates-hoogleraren, zoals Hans Achterhuis, Wouter Achterberg en Marcel Wissenburg wezen al op de blinde vlek van het humanisme voor onze plichten jegens niet-menselijk leven. Wouter Achterberg pleitte daarom voor een 'humanisme zonder arrogantie', een humanisme dat de mens niet als spil van het morele universum ziet. Ik zou gezien het voorgaande willen pleiten voor een humanisme dat ook het individu minder centraal stelt. Daarmee wil ik allerminst afbreuk doen aan de humanistische kernwaarden van autonomie en medemenselijkheid. Waar het mij vooral om gaat is een relativering van de kernwaarde van zelfontplooiing. Ik pleit voor een humanisme dat niet zozeer de ontplooiing van de individuele mens beoogt maar van de mens, het menselijk project, als zodanig. En voor die ontplooiing is een duurzame ontwikkeling essentieel.

Samenvattend: wat ik hier heb willen uiteenzetten is dat de bottleneck voor een duurzame ontwikkeling voornamelijk ligt in een tekort aan identificatie met toekomstige generaties. Een duurzame ontwikkeling vraagt verbondenheid met toekomstige generaties. Niet enkel vanuit medemenselijkheid en respect voor hun autonomie, maar vanuit het willen realiseren van gedeelde waarden en projecten die het individu overstijgen. De eigen identiteit verbonden zien met toekomstige generaties en de idee van waarden die het individu overstijgen, staan echter op gespannen voet met het moderne individualisme waarin niet zozeer de mens als zodanig de maat aller dingen is als wel de individuele mens. Individualisme waarin de hoogste waarden worden gegeven door autonomie, zelfbeschikkingsrecht, individuele ontplooiing en individuele behoeftebevrediging. De vraag is hoe we weer een partnerschap tussen de generaties kunnen terugkrijgen. Op die vraag ga ik mij graag vanuit deze leerstoel richten.

\section{Dankwoord}

Dat brengt mij op enkele woorden van dank. Bovenal ben ik de stichting Socrates en Maastricht University erkentelijk voor het vertrouwen dat zij in mij stellen. Ik zie het als een groot voorrecht om deze positie te mogen vervullen. Mijn nieuwe collega's van ICIS, 
het International Centre for Integrated assessment and Sustainable development, dank ik voor de warme ontvangst dat zij mij gaven en nog steeds geven.

Mijn promotor Ben van Linden van de Heuvell dank ik voor zijn open en nieuwsgierige geest tijdens mijn draai van de atoomfysica naar de milieuproblematiek. Mijn oud-collega's van milieuadviesbureau CE Delft dank ik voor hun collegialiteit in de beste en warmste betekenis van het woord. Zonder de bijzondere steun van Frans Rooijers had ik in 2003 niet de overstap kunnen maken naar de Universiteit van Amsterdam. De leden van de Capaciteitsgroep Philosophy \& Public Affairs aan de UvA dank ik voor mijn wijsgerige vorming, niet enkel tijdens mijn studie, maar tot op de dag van vandaag. Dat geldt met name voor mijn promotor in de wijsbegeerte, Govert den Hartogh, tegen wiens wijsheid in brede zin van het woord ik blijf opkijken. Ondanks de vriendelijke en constructieve toon van zijn adviezen realiseer ik mij daarbij telkens terdege: het enige wat ik weet, is dat ik niets weet. Wouter Achterberg is helaas niet meer in persoon te bedanken. Ik ben daarom blij, in plaats daarvan, volgende week vrijdag een naar hem vernoemde scriptieprijs te kunnen uitreiken op de Dag van de Milieufilosofie. Ook mijn collega's van het Instituut voor Biodiversiteit en Ecosysteemdynamica van de Universiteit van Amsterdam dank ik dat ik mij als vreemde eend in de bijt bij hen toch thuis voel.

Dank ben ik verschuldigd aan mijn goede vriend Mark de Koning. Dankzij onze vriendschap kan ik delen in zijn eruditie en inzichten, die hij pertinent weigert te etaleren via het geschreven woord.

Mijn ouders en broer wil ik bedanken voor al hun steun en oprechte interesse in mijn werk. Lieve Şeyma, Mira en Ilya. Jullie geven mijn leven zin.

Tot slot: mijn grootmoeder wilde tegen de buren nog wel eens haar teleurstelling uiten dat haar zoon gewoon hoogleraar was geworden en geen bijzonder hoogleraar. Jammer dat ze niet kan meemaken dat het haar kleinzoon wel is gelukt.

Ik heb gezegd. 


\section{Literatuur}

Achterberg, W., 1992. Humanisme zonder arrogantie: modern humanisme en ecocentrisme. Landbouwuniversiteit Wageningen, Wageningen.

Arrhenius, S., 1896. On the influence of carbonic acid in the air upon the temperature of the ground. The London, Edinburgh, and Dublin Philosophical Magazine and Journal of Science 41(251): 237-275.

Baumeister, R.F., 1991. Meanings of life. Guilford Press, New York.

Bowles, S., 2008. Policies designed for self-interested citizens may undermine the moral sentiments: Evidence from economic experiments. Science 320(5883): 1605-1609.

Burke, E., 1790. Reflections on the Revolution in France: and on the proceedings in certain societies in London relative to that event. In a letter intended to have been sent to a gentleman in Paris (No. 1-2). J. Dodsley.

Copson, A. and A.C. Grayling (eds.), 2015. The Wiley Blackwell Handbook of Humanism. John Wiley \& Sons, Hoboken.

Crutzen, P.J., 2006. The "anthropocene". Springer, Berlin Heidelberg.

Derkx, P.H.J.M., 2011. Humanisme, zinvol leven en nooit meer 'ouder worden'. Een levensbeschouwelijke visie op ingrijpende biomedisch-technologische levensverlenging.

ASP/VUBPRESS/UPA, Brussel.

Falk, A., \& Szech, N., 2013. Morals and markets. Science 340(6133): 707-711.

Feenberg, A., 1999. Questioning Technology. Routledge, London.

Frank, R.H., Gilovich, T., and Regan, D.T., 1993. Does studying economics inhibit cooperation? The Journal of Economic Perspectives 7(2): 159-171.

Hardin, G., 1968. The tragedy of the commons. Science 162(3859): 1243-1248.

Hume, D., 1739 (2012). A treatise of human nature. Courier Corporation, Mineola.

IPCC, 2014. Climate Change 2013. The Physical Science Basis. Contribution of Working Group I to the Fifth Assessment Report of the Intergovernmental Panel on Climate Change. Cambridge University Press, Cambridge, UK. 
Jamieson, D., 2014. Reason in a Dark Time: Why the Struggle Against Climate Change Failed--and what it Means for Our Future. Oxford University Press, Oxford.

Keat, R. and N. Abercrombie (eds), 1991. Enterprise Culture. Routledge, London.

Kunneman, H., 2005. Voorbij het dikke-ik: bouwstenen voor een kritisch humanisme. SWP publishers, Amsterdam.

Kunneman, H., 2007. 'Epiloog: een premie op de achterstand?' Humanistiek 8(29): 75.

Kymlicka, W., 1989. Liberal Individualism and Liberal Neutrality, Ethics 99(4): 883-905.

MacIntyre, A., 1985. After Virtue, 2nd ed., Duckworth, London.

Maslow, A., 1968. Toward a psychology of being. Van Nostrand, New York.

Montesquieu, C., 1748. De l'esprit des lois. Paris: Garnier, 1961.

O'Neill, J., 1993. Ecology, policy and politics: human well-being and the natural world. Routledge, London.

Orszag, P., 2007. Estimated costs of US operations in Iraq and Afghanistan and of other activities related to the war on terrorism. Congressional Budget Office (UC Congress), Washington DC.

Parfit, D., 1984. Reasons and Persons. Oxford University Press, Oxford.

Raz, J., 1986. The morality of freedom. Oxford University Press, Oxford.

Sandel, M.J., 2000. What money can't buy: the moral limits of markets. Tanner Lectures on Human Values 21: 87-122.

Sandel, M.J., 2012. What money can't buy: the moral limits of markets. Macmillan, Basingstoke.

Satz, D., 2010. Why some things should not be for sale: The moral limits of markets. Oxford University Press, Oxford.

Schwartz, B., 2012. Crowding out morality: How the ideology of self-interest can be self-fulfilling. Ideology, Psychology, and Law: 167.

Smith, A., 1776. An Inquiry into the Nature and Causes of the Wealth of Nations. Strahan, London.

Stiglitz, J.E., and Bilmes, L.J., 2008. The three trillion dollar war: The true cost of the Iraq conflict. WW Norton \& Company, New York. 
Thatcher, M., 1987. "AIDS, education, and the year 2000!," Woman's Own (October 31, 1987): 8-10. Available at http://www.margaretthatcher.org/document/106689

Titmuss, R.M., 1971. The Gift Relationship: From Human Blood to Social Policy. Pantheon Books, New York.

Walsh, A., 2001. Are Market Norms and Intrinsic Valuation Mutually Exclusive? Australasian Journal of Philosophy 79(4): 525-543.

WCED, 1987. Our common future: Report of the 1987 World Commission on Environment and Development. United Nations, Oslo.

White, L., Jr., 1967. The historical roots of our ecological crisis. Science 155: 1203-1207.

Wolff, J., 2004. "Moral Limits of the Market," unpublished manuscript.

Available at www.homepages.ucl.ac.uk/ uctyjow/MLM.doc 